\title{
Sobre el uso y la fetichización de los métodos cuantitativos
}

Miguel A. García

La diversidad de enfoques que componen las disciplinas abocadas al estudio de las expresiones musicales y sonoras, lejos está de tener una presencia completa en los números de El oído pensante publicados hasta el momento. Entre las ausencias se hallan enfoques que impulsan investigaciones basadas en la aplicación de métodos cuantitativos y en la búsqueda de respuestas con valor universal. A pesar de que la cuantificación a gran escala y el anhelo universalista han sido cuestionados desde posiciones humanistas y sociológicas, recientemente han aparecido artículos -publicados en revistas con alta visibilidad- que les confieren un lugar central dentro de sus procedimientos analíticos y expositivos. Estos trabajos provienen tanto de disciplinas que históricamente se valieron de los métodos cuantitativos y se orientaron hacia la búsqueda de enunciados universales, como de disciplinas devotas de los métodos cualitativos y esquivas a los universalismos que en los últimos años sucumbieron al encanto de los avances de la informática en relación con el manejo de grandes masas de datos.

Las humanidades digitales, área en curso de autodefinición en derredor de objetivos, métodos y mecanismos de validación derivados de distintas disciplinas, y de la expansión de los dispositivos y las técnicas de procesamiento digital, ofrecen una plataforma con prestigio institucional en aumento para la aplicación de métodos cuantitativos. Los resultados de una investigación que transita por los carriles de esa área se encuentra en el artículo "The Evolution of Popular Music: USA 1960-2010" (Mauch et al., 2015). Sus autores someten a análisis estadístico un corpus de 17.094 canciones citadas en el US Billboard Hot 100, entre los años 1960 y 2010, con la intención de "demostrar las tendencias cuantitativas en sus propiedades armónicas y tímbricas” y revelar si la variedad de canciones crece 
o disminuye a lo largo del período y si los cambios son continuos o discontinuos. ${ }^{1}$ Otro artículo que también recoge los resultados de un estudio llevado a cabo mediante el uso de métodos cuantitativos y herramientas informáticas, posee un título que pone al descubierto la inclinación universalista y evolucionista de sus autores/as: "Universality and Diversity in Human Song" (Mehr et al., 2019). La aplicación de un "análisis sistemático" (sic), lo cual implica la utilización de procedimientos informáticos para procesar una muestra con cálculo de error, hace concluir a sus autores/as que "la música es un hecho universal” y la tonalidad es "tal vez [también] universal". Asimismo concluyen que el canto presenta mayores variaciones en el interior de las sociedades que entre ellas; está asociado de manera regular a ciertos comportamientos; posee rasgos acústicos "sistemáticamente" relacionados con los objetivos de los cantantes y oyentes; varía en los planos formal, de la excitación -arousal-y religioso de acuerdo con los contextos; y que aparece ligado al lenguaje, la motricidad, la evaluación auditiva y a los patrones estéticos.

Una investigación que difiere de las anteriores, en cuanto a que la música no es objeto de estudio sino medio de representación de una estructura genética, pero que igualmente se vale de procedimientos lógico-matemáticos e informáticos, tuvo lugar este año en el Massachusetts Institute of Technology. Markus J. Buehler, músico y experto en estudio de materiales biológicos con técnicas computacionales, compuso una "obra" musical mediante el uso de algoritmos con el propósito de hacer audible la secuencia de aminoácidos y la estructura de la proteína de adsorción-spike protein- del patógeno COVID-19. La obra, titulada Viral Counterpoint of the Coronavirus Spike Protein (2019-nCOV), ${ }^{2}$ tiene una duración de 1 hora, 49 minutos, 48 segundos y fue instrumentada con sonidos de un cordófono japonés conocido como koto. Buehler explica que la conversión sonora de la estructura del COVID-19 tuvo dos objetivos: oír una complejidad que el ojo no puede discernir y mostrar cómo el virus engaña nuestros oídos de la misma manera que engaña a nuestras células -supuestamente los oyentes se ven seducidos por el carácter apacible de la representación sonora aun conociendo el hecho dramático de que el virus ha causado, al momento de escribir este Editorial, la muerte de más de medio millón de personas. ${ }^{3}$

\footnotetext{
${ }^{1}$ Ver una crítica previa en García (2015).

${ }^{2}$ Se puede escuchar en https://soundcloud.com/user-275864738/viral-counterpoint-of-the-coronavirus-spike-protein-2019-ncov

${ }^{3}$ Mayor información en http://news.mit.edu/2020/qa-markus-buehler-setting-coronavirus-andai-inspired-proteins-to-music-0402
} 
Las tres investigaciones mencionadas en los párrafos anteriores difieren en varios aspectos y merecen ser expuestas con mayor detalle a la par de una crítica atenta a sus premisas, al diálogo que establecen con investigaciones anteriores y, en particular, a los aportes que puedan o no constituir sus resultados. Pero dada la brevedad y el propósito de este Editorial, solo me referiré a lo que tienen en común, lo cual parece ser una estrategia que actualmente gana prestigio dentro del campo de las humanidades: el intento por comprender y representar expresiones musicales, prácticas asociadas a ellas y fenómenos no-sonoros mediante el lenguaje musical, apelando a procedimientos matemáticos, estadísticos e informáticos. No hay duda de que algunos interrogantes, aun en el campo de las humanidades, solo pueden ser respondidos a través del uso de métodos cuantitativos y que, en consecuencia, estos deben formar parte de los recursos que demandan los escenarios de investigación actuales, signados por transformaciones acaecidas en las condiciones de operatividad de los archivos y en los modos de circulación, almacenamiento y usos de las músicas. Frente al incesante incremento de los fondos, la accesibilidad y conectividad de los archivos y al actual estatus ontológico de los bienes culturales -bienes "en transferencia" por las redes digitales-, los métodos cuantitativos deben tener un lugar en el repertorio de las herramientas de las humanidades. No obstante, hay que tener en cuenta que en ocasiones los interrogantes que buscan responder las investigaciones no solo recurren a los métodos cuantitativos sino también son el producto de ellos. Es decir, los métodos anteceden a la duda y, por lo tanto, dan lugar a su formulación. Esta suerte de fetichización ocurre bajo las perspectivas que consideran los métodos cuantitativos como dispositivos infalibles y generadores de enunciados axiomáticos. Dejando de lado algunos resultados francamente muy cuestionables, el trabajo de Mehr et al. (2019) pone en evidencia otro de los riesgos de esa fetichización: el despliegue de una gran cantidad de cálculos para llegar a un conocimiento que podemos adquirir por la vía de la observación, la intuición y la experiencia.

Los algoritmos también merecen ser considerados. En el campo de la música son utilizados en software para procesar sonido, generar acompañamientos instrumentales y vocales, y aun componer; en el control de instrumentos musicales digitales; la creación de personajes virtuales en conjunción con desarrollos de la inteligencia artificial -como la conocida Hatsune Miku-; la conformación de perfiles de consumidores para diseñar estrategias de venta; la predicción del éxito comercial de una canción; etc. Si bien en todas estas aplicaciones los algoritmos parecen satisfacer el nivel de rendimiento deseado, su eficacia es cuestionable en la creación de una obra musical a partir de la secuencia de aminoácidos y la estructura 
de la proteína de adsorción del COVID-19, tal como lo efectuó Buehler. El problema más significativo radica en que la supuesta rigurosidad lógicomatemática del procedimiento se quiebra en uno de los puntos más sensibles de la representación musical del virus: las correspondencias entre el código genético y las variaciones de frecuencia y duración sonoras, como así también en la selección del timbre -proveniente de las pulsaciones de las cuerdas del koto-. La asignación de estas correspondencias es en un sentido arbitraria, es decir, no hay justificación para asignar a un determinado rasgo genético una frecuencia y no otra, o a una duración y no otra. Aun si este inconveniente pudiese atenuarse, no se vislumbra cómo la sonorización puede hacer comprensible aspectos del virus de manera más eficaz de lo que lo hacen los instrumentos de la biología y mucho menos cómo los oyentes, poseedores de una inmensa variedad de experiencias y expectativas, reconozcan por igual el engaño que produce el virus.

Más allá de estas críticas y de otras que puedan hacerse a la fetichización de los métodos cuantitativos, a la persistencia de aspiraciones universalistas y a los usos de los recursos de la informática para representar y analizar expresiones musicales y diversas prácticas que las acompañan, no dejan de ser bienvenidas investigaciones como las mencionadas. Pues, cuanto más discrepancias encontremos entre ellas más estimulante y fructífero será el debate y, de esta manera, más contribuiremos a concretar uno de los principales objetivos de El oído pensante: la promoción de un pensamiento crítico capaz de desmantelar los conceptos de uso corriente y abrir nuevas perspectivas. 


\section{Q Bibliografía}

» García, M. A. (2015). El desafío de las humanidades digitales. El oído pensante, 3(2), 1-3. Recuperado de http://revistascientificas.filo.uba.ar/ index.php/oidopensante/article/view/7459

» Mauch, M., MacCallum, R. M., Levy (Last-fm), M., and Leroi, A. M. (2015). The Evolution of Popular Music: USA 1960-2010. Royal Society Open Science, 2, 1-10. Recuperado de http://rsos.royalsocietypublishing.org/ content/2/5/150081

»Mehr, S. A. et al. (2019). Universality and Diversity in Human Song. Science, 366, 1-17. Recuperado de http://dx.doi.org/10.1126/science.aax0868 